JCD: Journal of Community Development and Disaster Management Vol 1 No 2 | Juli 2019

\title{
Peran Dana Desa Dalam Memberdayakan Masyarakat Ditinjau Dari Perspektif Ekonomi Islam Study Di Desa Galak Kec. Slahung Kab. Ponorogo
}

\author{
Marekan \\ Institute Agama Islam Sunan Giri Ponorogo \\ marekan21@gmail.com \\ Teguh Ansori \\ Institute Agama Islam Sunan Giri Ponorogo \\ teguhanshory586@gmail.com
}

\begin{abstract}
Abstrak
Dana Desa adalah dana yang bersumber dari Anggaran Pendapatan dan Belanja Negara yang diperuntukan bagi Desa yang ditransfer melalui Anggaran Pendapatan dan Belanja Daerah Kabupaten/kota yang digulirkan dari tahun 2015 bertujuan untuk membiayai penyelenggaraan pemerintahan, pelaksanaan pembangunan, pembinaan dan pemberdayaan masyarakat. Dana Desa memiliki peran penting dalam peningkatan ekonomi masyarakat desa, dengan pemanfaatan dan pengalokasian yang efektif dan efisien, Penelitian ini merupakan penelitian kualitatif dengan tujuan utama untuk mendeskriptifkan atau melukiskan secara detail dan mendalam mengenai proses pelaksanaan dana desa sehingga dapat memberikan peran / kontribusi sesuai yang diharapakan pemerintah pusat. Dari hasil penelitian pengolahan dana desa yang ada di Desa Galak Kec. Slahung, Kab Ponorogo, berjalan dengan berpatokan pada petunjuk teknis yang ada sehingga pemberdayaan masyarakat dari tahun 2015 sampai pada tahun 2018 mulai meningkat dilihat dari pembangangunan namun masih minim dalam peningkatan pemberdayaan perekonomian masyarakat. Kebijakan yang dilaksanakan pemerintah dalam melaksanakan tugasnya perpatokan dengan nilai dasar ekonomi islam yaitu: kepemilikan, keseimbangan dan keadilan. Pemerintah bekerja sama dengan lembaga yang ada di desa, serta keputusan-keputusan yang diambil oleh pemerintah merupakan keputusan bersama dalam Musyawarah Rencana Pembangunan Desa (Musrenbangdes).
\end{abstract}

\section{Kata Kunci : Dana Desa, Pemberdayaan Masyarakat, Ekonomi}

\begin{abstract}
Village Funds are funds sourced from the State Revenue and Expenditure Budget allocated to Villages which are transferred through the Regency / City Regional Income and Expenditure Budget which was rolled out from 2015 with the aim of financing governance, implementation of development, guidance and community empowerment. Village funds have an important role in improving the economy of village communities, with effective and efficient use and allocation. This research is a qualitative research with the main objective of describing or describing in detail and in-depth the process of implementing village funds so that they can provide roles / contributions as expected. Central government. From the results of research on village fund processing in Galak Village, Kec. Slahung, Ponorogo District, runs based on existing technical guidelines so that community empowerment from 2015 to 2018 has begun to increase in terms of development but is still minimal in increasing the empowerment of the community economy. The policies implemented by the government in carrying out their duties are based on the basic values of Islamic economics, namely: ownership, balance and justice. The government collaborates with existing institutions in the village, and decisions taken by the government are joint decisions in the Village Development Planning Consultation (Musrenbangdes).
\end{abstract}




\section{Keywords: Village Fund, Community Empowerment, Economy Pendahuluan}

Dalam Undang-Undang Nomor 33 Tahun 2004 tentang perimbangan keuangan pusat daerah, dimana hal ini disambut positif dari semua pihak dengan segenap harapan bahwa melalui otonomi daerah akan dapat merangsang terhadap adanya upaya untuk menghilangkan praktekpraktek sentralistik yang pada satu sisi dianggap kurang menguntungkan bagi daerah dan penduduk lokal. Prinsip otonomi daerah menggunakan prinsip otonomi seluas-luasnya dalam arti daerah diberikan kewenangan mengurus dan mengatur semua urusan pemerintahan di luar yang menjadi urusan Pemerintah yang ditetapkan dalam Undang-Undang (Dana, 2014).

Proses desentralisasi yang telah berlangsung telah memberikan penyadaran tentang pentingnya kemandirian daerah yang bertumpu pada pemberdayaan potensi lokal. Meskipun pada saat ini kebijakan yang ada masih menitik beratkan otonomi pada tingkat Kabupaten/Kota, namun secara esensi sebenarnya kemandirian tersebut harus dimulai dari level pemerintahan ditingkat paling bawah yaitu Desa. Pemerintah Desa diyakini lebih mampu melihat kebutuhan yang harus lebih di prioritaskan masyarakat dibandingkan Pemerintah Kabupaten yang secara nyata memiliki ruang lingkup permasalahan lebih luas dan rumit. Untuk itu, pembangunan pedesaan yang dilaksanakan harus sesuai dengan masalah yang dihadapi, potensi yang dimiliki, aspirasi masyarakat dan prioritas pembangunan pedesaan yang telah ditetapkan.

Berdasarkan pada Peraturan Pemerintah Nomor 60 Tahun 2014 Tentang Dana Desa yang bersumber dari Anggaran Pendapatan dan Belanja Negara, pada ayat pasal yang telah diamandemen pada Peraturan Pemerintah Nomor 168 tahun 2014 ke 11 ayat 2 yang menyatakan bahwa dana desa dialokasikan secara berkeadilan berdasarkan: Alokasi yang dihitung memperhatikan jumlah penduduk, angka kemiskinan, luas wilayah, dan tingkat kesulitan geografis desa setiap kabupaten/kota.

Dalam UU Nomor 6 Tahun 2014 tentang Desa, yaitu adanya komitmen negara dalam melindungi dan memberdayakan desa agar menjadi kuat, maju, mandiri dan demokratis sehingga dapat menciptakan landasan yang kuat dalam melaksanakan pemerintahan dan pembangunan menuju masyarakat yang adil, makmur dan sejahtera.

Selanjutnya juga diharapkan akan terwujudnya desa yang mandiri dimana :

1. Desa bukan hanya sekedar sebagai obyek penerima manfaat, melainkan sebagai subyek pemberi manfaat bagi warga masyarakat setempat; 
2. Sebagai komponen desa mempunyai rasa kebersamaan dan gerakan untuk mengembangkan aset lokal sebagai sumber penghidupan dan kehidupan bagi warga masyarakat.

3. Desa mempunyai kemampuan menghasilkan dan mencukupi kebutuhan dan kepentingan masyarakat setempat seperti pangan, energi, layanan dasar dll;

Sebagai cita-cita jangka panjang, desa mampu menyediakan lapangan pekerjaan, menyediakan sumber-sumber pendapatan bagi masyarakat serta menghasilkan pendapatan asli desa dalam jumlah yang memadai (Sholeh, 2015). Dengan demikian pemerintah desa harus mengambil tindakan dari adanya kebijakan pemerintah pusat yang telah menggulirkan Dana Desa sebagai stimulus pembangunan desa secara adil dan merata dalam pembangunan. Peran pemerintah dalam membangun desa sangat penting dimana pemerintah adalah unit pelaksana utama dalam pembangunan yang akan dibantu oleh beberapa lembaga yang lain seperti Badan Permusyawaratan Desa (BPD) dan Lembaga Pemberdayaan Masyarakat (LPM) serta Masyarakat Desa.

Berkenaan dengan desentralisasi/otonomi maksud pemberian Dana Desa (DD) adalah sebagai bantuan stimulan atau dana perangsang untuk mendorong dalam membiayai program Pemerintah Desa yang ditunjang dengan partisipasi swadaya gotong royong masyarakat dalam melaksanakan kegiatan pemerintahan dan pemberdayaan masyarakat. Melihat pada apa yang diamanatkan melalui dana desa ini, program pembangunan dan pemberdayaanlah yang memang menjadi tujuan utamanya, dan peran pemerintah desa dalam hal ini menjadi kunci bagaimana mengalokasikan dana tersebut dengan semestinya, yakni untuk pembangunan dan pemberdayaan.

Maka dari itu, pemerintah desa harus kembali pada tugas pokok dan fungsinya sebagai pemimpin desa, yakni diantaranya:

1. Membina kehidupan masyarakat desa.

2. Membina ekonomi desa.

3. Mengordinasikan pembangunan desa secara partisipatif.

4. Melaksanakan wewenang lain sesuai dengan peraturan perundang undangan.

Dari data sementara yang penulis peroleh dari Laporan Anggaran Pendapatan dan Belanja Desa (APBDes) Desa Galak. 
Tabel 1.1

Dana Desa yang diterima Desa Galak Periode 2015-2018

\begin{tabular}{|c|c|c|}
\hline No & Tahun & \multicolumn{1}{|c|}{ Jumlah } \\
\hline 1 & 2015 & Rp. 266.720.000.00 \\
\hline 2 & 2016 & Rp. 598.076 .000 .00 \\
\hline 3 & 2017 & Rp. 762.135 .000 .00 \\
\hline & & Rp. 696.410 .000 .00 \\
\hline & 2018 & Rp. 2.323.341.000.00 \\
\hline
\end{tabular}

Sumber: APBD Desa Galak Tahun 2015-2018

Beberapa program atau kebijakan pemerintah desa Galak yang telah dilakukan pada tahun 2015 yang bertujuan untuk meningkatkan pemberdayaan masyarakat diantaranya adalah program pembangunan pengerasan jalan, pembangunan drainase dan pembangunan goronggorong. Sedangkan pada tahun 2016 digunakan untuk melanjutkan beberapa program yang belum terselesaikan pada tahun sebelumnya, seperti pengerasan jalan perlintasan ekonomi masyarakat dan pengadaan perpustakaan desa. Setelah dua tahun berturut pemerintah dapat menjalankan beberapa program secara maksimal dibandingkan dengan sebelum adanya dana desa sebagai pendorong pembangunan dan pemberdayaan.

Pemberdayaan (empowerment) merupakan sebuah konsep yang lahir sebagai bagian dari perkembangan alam pikiran dan kebudayaan masyarakat Barat, terutama Eropa. Konsep ini muncul sejak dekade 70an dan kemudian terus berkembang sampai saat ini. Kegagalan pembangunan menjadi dasar pemberdayaan masyarakat yang disebabkan oleh pendekatan konvensional diantaranya adalah transplantative planning, top down, inductive, capital intensive, west-biased technologicaltransfer, dan sejenisnya (Dwijayanto, 2018).

Arah pemberdayaan masyarakat desa yang paling efektif dan lebih cepat untuk mencapai tujuan adalah dengan melibatkan masyarakat (masyarakat umum, masyarakat kurang mampu) dan unsur pemerintahan yang memang menggunakan kebijakan pembangunan yang lebih reaktif memberikan prioritas kebutuhan masyarakat desa dalam alokasi anggaran. Pembangunan desa dengan pemberdayaan masyarakat langsung memiliki hasil yang lebih efektif dan efisiensi 
dibandingkan dengan pembangunan desa dengan menggunakan tenaga proyek ataupun pekerja dari desa lain.

Salah satu pola pendekatan pemberdayaan masyarakat paling efektif dalam rangka peningkatan partisipasi masyarakat adalah merangsang masyarakat untuk mampu mengidentifikasi keinginan dan kebutuhan bekerja secara kooperatif dan menumbuhkan rasa gotong-royong sesama warga desa. Dana Desa merupakan salah satu alat untuk membantu terlaksananya pemerintahan desa, pembangunan desa, dan pemberdayaan masyarakat dalam upaya meningkatkan perekonoian masyarakat. Dengan adanya dana desa ini, diharapkan agar dapat membantu masyarakat dalam segi kebutuhan, pembangunan sarana dan prasarana, serta dapat mengembangkan potensi ekonomi local yang didasarkan atas kondisi dan potensi desa. Namun, pengelolaan dana desa Galak dalam pemberdayaan perekonomian masyarakat belum dapat terwujud karna pemerintah desa masih terfokus dalam pembangunan infrastruktur desa.

Islam memandang suatu keberdayaan atas masyarakat adalah hal yang penting sehingga pemberdayaan dalam pandangan Islam memliki paradigma yang holistik dan strategis. Pemberdayaan dalam konteks pengembangan masyarakat islam merupakan sebuah pembelajaran kepada masyarakat agar dapat mandiri melakukan upaya perbaikaan kualitas hidup yang menyangkut tentang kesejahteraan dan keselamatan dunia dan akhirat.

Salah satu pentingnya pemberdayaan masyarakat dalam Islam perlunya diterapkan adalah karena dengan adanya pemberdayaan akan menghasilkan pembangunan yang berkelanjutan. Dengan hal seperti ini maka akan terus dapat memperbaiki taraf hidupnya ke yang lebih baik. Dalam agama Islam memiliki konsep pemberdayaan masyarakat dalam kitab suci yaitu Alqur'an Q.S Ar-Ra'd ayat 11: Artinya: "Sesungguhnya Allah tidak merobah Keadaan sesuatu kaum sehingga mereka merobah keadaan yang ada pada diri mereka sendiri. Dan apabila Allah menghendaki keburukan terhadap sesuatu kaum, Maka tak ada yang dapat menolaknya.

Berdasarkan ayat Ar-Ra'd ayat 11 yang menyebutkan bahwa Tuhan tidak akan merubah Keadaan mereka, selama mereka tidak merubah sebab-sebab kemunduran mereka. Sejalan dengan teori pemberdayaan masyarakat yang mana melalui pemberdayaan masyarakat dapat memiliki inisiatif dan kemampuan untuk mengelola sendiri sumber daya mereka. Sehingga dengan mereka dapat mengelola dan membentuk penggalian kemampuan pribadi, kreatifitas, kompetensi dan daya pikir dapat merubah kehidupannya pula dengan kemampuan dan keahlian yang dimiliki. 


\section{Metode Penelitian}

Metode Penelitian adalah cara evaluasi, analisis, dan seleksi berbagai alternatif, cara atau teknik. Metode ilmiah adalah cara menerapkan prinsip-prinsip logis terhadap penemuan, pengesahan, dan penjelasan. Metode penelitian harus logis, diikuti unsur-unsur yang urut, konsisten, dan operasional, menyangkut bagaimana penelitian tersebut akan dijalankan (Suharto 2014). Penelitian ini termasuk penelitian lapangan (field research) yaitu penelitian yang dilakukan dilapangan dalam lingkup kehidupan yang sebenarnya (Hasan, 2012). Penelitian lapangan dilakukan dengan menggali data yang bersumber dari lokasi atau lapangan penelitian terhadap responden yang ada di Desa Galak Kecamatan Slahung.

Penelitian ini bersifat deskriptif yaitu suatu penelitian yang bertujuan untuk menggambarkan secermat mungkin mengenai sesuatu yang menjadi objek, gejala atau kelompok tertentu serta menjawab persoalan-persoalan tentang fenomena dan peristiwa yang terjadi saat ini (Sugiyono, 2010).

\section{Hasil Penelitian dan Pembahasan}

Peranan (role) merupakan aspek yang dinamis dari kedudukan (status). Peranan dapat membimbing seseorang dalam berperilaku, karena fungsi peran sendiri adalah untuk memberikan arah pada proses sosialisasi, pewarisan tradisi, kepercayaan, nilai-nilai, normanorma dan pengetahuan. Peranpun dapat mempersatukan kelompok atau masyarakat, serta dapat menghidupkan sistem pengendali dan kontrol, sehingga dapat melestarikan kehidupan masyarakat (Narwoko, 2014).

Istilah desa berasal dari bahasa india swadesi yang berarti tempat asal, tempat tinggal, negeri asal atau tanah leluhur yang merajuk pada suatu kesatuan hidup dengan kesatuan hidup dengan kesatuan norma serta memiliki batas yang jelas. Istilah desa dan pedesaan sering dikaitkan dengan pengertian rural dan village yang dibandingkan dengan kota (city/town) dan perkotaan (urban). Konsep perdesaan dan perkotaan mengacu kepada karakteristtik masyarakat, sedangkan desa dan kota merajuk pada suatu wilayah administrasi atau tutorial, dalam hal ini perdesaan mencakup beberapa desa. Definisi tentang atan panjang di kalangan para ahli. Desa dibentuk berdasarkan kebutuhan masyarakat di daerah satu desa sendiri sampai sekarang belum dikaji karena batasannya menjadi perdebengan daerah lain yang berbeda kulturnya. Beberapa 
para ahli atau pakar mengemukakan pendapatnya dari tinjauannya masing-masing (Numan, 2015). Dalam UU RI Nomor 22 tahun 1999, desa sebagai suatu kesatuan masyarakat hukum yang memiliki kewenangan untuk mangatur dan mengurus kepantinagn masyarakat berdasarkan asal-usul dan adat istiadat setempat yang diakui dalam sistem pemerintahan nasional dan berada di daerah kabupaten. Pengertian ini mengandung makna dan konsekuensi logis dalam penataan sistem pemerintahan dan birokrasi. Hal-hal yang mendasari penyelenggaraan pemerintahan dan birokarasi desa sebagai berikut:

1. Landasan pemikiran dalam pengaturan tentang pemerintahan desa adalah keanekaragaman, partisipasi, otonomi asli, demokratisasi, dan pemberdayan masyarakat.

2. Penyelenggaraan pemerintah desa merupakan bagian atau subsistem dari sistem penyelenggaraan pemerintahan sehingga desa memilki kewenangan untuk mengatur dan mengurus kepentingan masyarakat. Kepala desa bertanggung jawab pada Badan Permusyawaratan Desa (BPD) dan menyampaikan laporan pelaksanaan tugas itu kepada bupati.

3. Desa dapat melakukan perbuatan hukum, baik hukum publik maupun hukum perdata, memiliki kekayaan, harta benda, dan bangunan serta dapat di tuntut dan menuntut di pengadilan. Oleh karena itu, kepala desa mempunyai wewenang untuk melakukan perbuatan hukum dan mengadakan perjanjian yang saling menguntungkan.

4. Sebagai perwujudan demokrasi, didesa dibentuk Badan Permusyawaratan Desa (BPD) yang berfungsi sebagai lembaga legalitas dan pengawasan dalam hal pelaksanaan peraturan desa, anggaran pendapatan dan belanja desa, dan keputusan kepala desa.

5. Di desa dibentuk lembaga kemasyarakatan desa lainnya sesuai dengan kebutuhan. Lembaga ini bertujuan sebagai mitra pemerintahan desa dalam rangka pemberdayaan masyarakat desa.

6. Desa memiliki sumber pembiayaan berupa pendapatan desa, bantuan pemerintah dan pemerintah daerah, pendapatan lainnya yang sah, sumbangan pihak ketiga dan pinjaman desa.

7. Berdasarkan hak asal-usul desa yang bersangkutan, kepala desa mempunyai wewenang untuk mendamaikan perkara atau sengketa dari para warganya. 
Pembangunan desa dan pembangunan masyarakat desa telah menjadi dua istilah yang sering di campuradukan pengertiannya. Padahal secara definisi keduanya memiliki pengertian yang sedikit berbeda. Sumarja, menyebutkan bahwa pembangunan masyarakat desa (community development) adalah usaha pembangunannya hanya diarahkan pada kualitas manusianya, sedangkan pembangunan desa (rural development) mengusahakan pembangunan masyarakat yang dibarengi lingkungan hidupnya.

Desa sebagai satuan pemerintahan terkecil yang langsung berinteraksi dengan masyarakat. Desa dengan kultur masyarakat dapat lebih terpelihara dan dikembangkan dengan produktif untuk kehidupan dan penghidupan, di tingkat desa tempat dilaksanakannya berbagai program pemberdayaan masyarakat serta adanya kearifan lokal yang kuat yang harus diakomodasi dalam pengurangan resiko (Hijri, 2020).

Dana Desa adalah dana yang bersumber dari Anggaran Pendapatan dan Belanja Negara yang diperuntukan bagi Desa yang di transfer melalui Anggaran Pendapatan dan Belanja Daerah Kabupaten/kota dan digunakan unuk membiayai penyelenggaraan pemerintahan, pelaksanaan pembangunan, pembinaan, kemasyarakatan dan pemberdayaan masyarakat (Saiban 2014).

Berdasarkan pada Peraturan Pemerintah Nomor 60 Tahun 2014 Tentang Dana Desa yang bersumber dari Anggaran Pendapatan dan Belanja Negara, pada ayat pasal yang telah diamandemen pada Peraturan Pemerintah Nomor 168 tahun 2014 ke 11 ayat 2 yang telah dipertimbangkan dan dirumuskan dalam pengalokasian dana desa menyatakan bahwa dana desa dialokasikan secara berkeadilan berdasarkan: Alokasi yang dihitung memperhatikan jumlah penduduk, angka kemiskinan, luas wilayah, dan tingkat kesulitan geografis desa setiap kabupaten/kota.

Falsafah pemberdayaan masyarakat dapat dikatakan sebagai kerjasama dengan masyarakat untuk meningkatkan taraf hidup mereka. Pemberdayaan semakin popular dalam konteks pembangunan dan pengentasan kemiskinan yang terjadi pada saat ini. konsep pemberdayaan yang diusung adalah untuk melihat yang tidak berdaya atau lemah (powerless) (Anwas, 2014). Oleh karena itu, pemberdayaan sangat berpengaruh terhadap proses pembentukan masyarakat yang sejahtera. Pemberdayaan masyarakat merupakan suatu strategi yang banyak diterima dan dikembangkan. Dimana pemberdayaan harus berpihak pada pentingnya individu didalam perjalanan pertumbuhan masyarkat dan bangsanya. 
Pemberdayaan dilakukan secara bertahap, berkesinambungan dan dilakukan secara terus menerus, bersabar dan telaten. Filosofi pemberdayaan adalah bekerja bersama masyarakat untuk membantu agar mereka dapat meningkatkan harkatnya sebagai manusia (helping people to help themselves) (Sulistiani, 2004). Pengertian pemberdayaan masyarakat Islam adalah suatu proses atau tindakan yang terjadi di Indonesia dengan memberikan rasa tanggung jawab terhadap konteks ekonomi. Dengan demikian masyarakat muslim dituntut untuk lebih keras untuk bekerja, berinteraksi, dan berwirausaha.

Menurut Saefudin nilai-nilai dasar pemberdayan ekonomi dibagi menjadi tiga yaitu:

\section{Kepemilikan (ownership)}

Pemilikan terletak pada kemanfaatannya dan bukan menguasai secara mutlak terhadap sumber-sumber ekonomi. Seorang muslim yang tidak memproduksi manfaat dari sumber-sumber yang diamanatkan Allah padanya akan kehilangan hak atas sumber-sumber tersebut. kepemilikan terbatas sepanjang usia hidup manusia di dunia dan bila orang itu mati harus didistribusikan atau dialihkan kepemilikannya kepada ahli warisnya menurut ketentuan Islam.

\section{Keseimbangan}

Pengaruh faktor keseimbangan terlihat pada berbagai praktek ekonomi Islam, misalnya kesederhanaan, berhemat dan menjauhi pemborosan. Onsep keseimbangan ini tidak hanya timbangan kebaikan hasil usahanya diarahkan untuk di dunia dan diakhirat saja, tetapi berkaitan juga dengan kepentingan (kebebasan) perorangan dengan kepentingan umum yang harus dipelihara, dan keseimbangan antara hak dan kewajiban harus direalisasikan.

\section{Keadilan}

Kata keadilan disebut lebih dari 1000 kali menunjukkan betapa nilai dasar ini memiliki bobot yang sangat dimuliakan dalam Islam, selain itu kata yang paling banyak disebut dalam AlQur'an setelah Allah dan ilmu pengetahuan, ialah keadilan. Baik yang berkaitan dengan aspek sosial, politik, maupun ekonomi. Seorang ulama kontemporer yang bernama Yusuf Al-Qardhawi menyatakan bahwa, "Ruh sistem Islam merupakan pertengahan yang adil (Abbas, 2012).

Wilayah Desa Galak terletak di antara Arah Kiblat : $24^{\circ} 27^{1}$ BU Lintang : $7^{\circ} 52^{1}$ LS Bujur $111^{\circ} 29^{1}$ BT, Tinggi Tempat $115 \mathrm{~m}$

Terletak diatas permukaan Laut 115 M Desa Galak mempunyai luas 154.600 Ha. Lahan pekarangan seluas 36.425 Ha. Lahan pertanian sawah tadah hujan 96.165ha dan lahan perladangan 4,41 ha. 
Adapun batas-batas Wilayah Desa Galak adalah :

a. Sebelah Uatara, berbatasan dengan Desa Gundik Kecamatan Slahung.

b. Sebelah Timur, berbatasan dengan Desa Truneng dan Desa Simo Kecamatan Slahung.

c. Sebelah Selatan, berbatasan dengan Desa Menggare Kecamatan Slahung.

d. Sebelah Barat, berbatasan dengan Desa Jebeng Kecamatan Slahung.

Wilayah Desa Galak Kecamatan Slahung Kabupaten Ponorogo terdiri dari Tiga wilayah Pedusunan, 13 RT dan 6 RW, yakni Dusun Maron terdiri dari 4 RT dan 2 RW, Dusun Galak terdiri dari 4 RT dan 2 RW, Dusun Terpatih 5 RT dan 2 RW.

Dalam Peraturan Pemerintah Nomor 60 Tahun 2014 tentang Dana Desa yang bersumber dari APBN, Pasal 1, ayat 2 Dana Desa adalah Dana yang bersumber dari Anggaran Pendapatan dan Belanja Negara yang diperuntukkan bagi Desa yang ditransfer melalui Anggaran Pendapatan dan Belanja Daerah Kabupaten/Kota dan digunakan untuk membiayai penyelenggaraan pemerintahan, pelaksanaan pembangunan, pembinaan kemasyarakatan, dan pemberdayaan masyarakat. Tujuan dari dana desa pada dasarnya adalah mewujudkan pertumbuhan ekonomi yang inklusif dengan lebih memeratakan pendapatan.

Berbicara mengenai upaya-upaya pemerintah desa dalam meningkatkan pemberdayaan masyarakat, tentunya hal ini sangat berkaitan erat dengan peran pemerintah desa sendiri. Menyinggung perihal peran dari suatu kinerja, hal terserbut tentunya tidak akan terlepas dari yang namanya kualitas. Kualitas dari tugas pemerintah desa yang dimaksud di sini adalah sejauh mana pemerintah desa mampu menyelenggarakan aktifitas-aktifitas pembangunan ataupun pemberdayaan masyarakat. Aktifitas pembangunan ataupun pemberdayaan masyarakat ini diharapkan dapat membantu masyarakat dalam kehidupan perekonomian serta kepentingan rakyat desa secara umum. Selain itu, segala aktifitas yang dilakukan oleh pihak pemerintah desa diharapkan mampu menciptakan perubahan bagi kehidupan masyarakat secara signifikan di segala segi kehidupannya.

Membahas mengenai bagaimana dan seperti apa aktifitas pelaksanaan program yang dilakukan oleh pemerintah desa, maka hal ini tidak akan terlepas dari tahapan-tahapan dalam bagaimana pemerintah desa melaksanakan suatu program, khususnya dalam hal ini adalah pemberdayaan melalui dana desa. 
Menurut Kaur Kesejahteraan Rakyat Desa Galak yaitu Bpk. Zainal Arifin menyatakan bahwa tahapan atau proses pemberdayaan masyarakat melalui program dana desa adalah melalui program-program kerja desa, yang mekanismenya dimulai Pertama, pemerintah desa mengadakan musyawarah kedusunan (MUSDUS) di setiap kedusunan dan dihadiri oleh setiap elemen masyarakat di kedusunan, yang tujuannya adalah untuk menampung aspirasi masyarakat, program apa saja yang diinginkan oleh masyarakat, serta yang harus direalisasikan oleh pemereintah desa dalam satu tahun anggaran atau satu periode pemerintahan.

Dalam pelaksanaannya, MUSDUS dilakukan sebelum awal tahun anggaran, tepatnya di Desa Galak dilaksanakan pada Oktober 2017, yang didalamnya melibatkan ketua RT, serta tokoh-tokoh masyarakat. Di Desa Galak sendiri terdapat 3 (Tiga) kedusunan yang terdiri dari 13 RT, maka dari itu MUSDUS akan dilaksanakan 3 (Tiga) kali. Dalam kegiatan MUSDUS tersebut masyarakat mengajukan beberapa aspirasinya, yakni pembangunan jalan dan pengadaan Irigasi bagi para petani di kampung tersebut.

Kedua, setelah semua hasil MUSDUS tertampung, serta semua aspirasi di setiap kedusunan tertampung, maka dilanjutkan dengan MUSDES (Musyawarah Desa), yang dihadiri oleh tokoh agama, pemuda, ibu-ibu, yang tujuannya adalah untuk menentukan skala prioritas program apa saja yang harus didahulukan di lapangan.

\section{Kesimpulan}

Berdasarkan proses penelitian yang dilakukan, maka dapat ditarik kesimpulan sebagai berikut: Pemberdayaan masyarakat Desa Galak sebelum adanya dana desa memang belum mampu dirasakan oleh masyarakat secara keseluruhan. Selain itu, keadaan infrastruktur sebagai salah satu penunjang akan kegiatan pertumbuhan masyarakat dalam berbagai bidang, keadaanya belum begitu baik. Hal ini dapat dilihat dari keadaan beberapa jalan penghubung antar desa dibeberapa wilayah yang masih rusak, begitu juga jembatan, serta belum ada pembangunanpembangunan yang ditujukan untuk meningkatkan pemberdayaan masyarakat. Setelah adanya dana desa masyarakat mulai merasakan adanya dampak yang positif terlihat dari adanya kerjasama pemerintah dan masyarakat dalam peningkatan pembangunan sarana dan prasarana desa seperti pembangunan jalan, jembatan, gorong-gorong perbaikan fasilitas desa dan kegiatan pemberdayaan yang bertujuan meningkatkan perekonomian masyarakat Desa Galak. 


\section{Daftar Pustaka}

A saibani. (2014). Pedoman Umum Penyelenggaraan Pemerintahan Desa, Jakarta: Media Pustaka..

Abbas, Anwar (2012) "Sistem Ekonomi Islam: Suatu Pendekatan Filsafat, Nilai-nilai Dasar, dan Instrumen” Jurnal Ilmiah Ekonomi Islam Al-Iqtishad Vol: IV. No 1.

Alokasi Dana Desa (Add) Dan Kemiskinan Di Provinsi Jawa Timur, Jurnal Ekonomi Pembangunan, Volume 12, No.1 (Juni 2014), 29 - 41

Anwas, Oos M., (20140. Pemberdayaan Masyarakat di Era Global, Bandung, Alfabeta.

Dwijayanto, A. (2018). Pemberdayaan Komunitas Muslim Perbukitan Melalui Program Sosial Bank Indonesia di Kaur Bengkulu. MUHARRIK: Jurnal Dakwah Dan Sosial, 1(02), 155-167. https://doi.org/10.5281/zenodo.3545555

Hasan, Iqbal, (2012). Pokok-Pokok Materi Metodologi Dan Aplikasinya, Bogor: Ghalia Indonesia.

Hijri, Y., Kurniawan, W., \& Hilman, Y. (2020). Praktik Penyusunan Peraturan Desa (Perdes) sebagai Penguatan Desa Tangguh Bencana di Kabupaten Malang. Amalee: Jurnal Riset dan Keterlibatan Masyarakat Indonesia, 1 (1), 111. https://doi.org/10.37680/amalee.v1i01.131

Mutthoriq dkk, "Aktualisasi Nilai Islam Dalam Pemberdayaan Masyarakat”, Jurnal Administrasi Publik (JAP), Vol 2, No 3.

Narwoko, dan Bagong Suyanto, (2014). Sosiologi Teks Pengantar Dan Terapan, Jakarta. KENCANA.

Numan,(2015). Strategi Pembangunan Daerah, Jakarta: Raja Grafindo Persada.

Sholeh, Chabib dan Heru Rochansjah, (2015). Pengelolaan Keuangan Desa, Bandung: FOKUS MEDIA.

Sugiyono, (2010). Metode Penelitian Bisnis (Pendekatan Kuantitatif, Kualitatif Dan R\&D), Bandung: Alfabeta.

Suharto, dkk, (2004). Perekayasan Metodologi Penelitian, Yogyakarta, Andi, 2004.

Sulistiani, Ambar Teguh, (2004). Kemitraan dan Model-Model Pemberdayaan, Yogyakarta: Gava Media. 